Materiały spotkania biblijnego w Grazu 1987 ukażą się z pewnością w herderowskiej serii "Quaestiones disputatae” (podobnie jak z poprzednich sesji) i wơwczas otrzymamy wartościową publikację na temat procesu Jezusa, o którym pisze teolog żydowski Pinchas Lapide w "Die Welt": "Mimo że proces przeciw Jezusowi trwał zaledwie kilka godzin, był to najdłuższy proces $w$ historii świata; jego następstwa trwają wciąż jeszcze ziejąc nienawiść między chrześcijanami a Żydami. A co więcej proces ten pozostaje sporny po dziś dzień" (cyt. za „Forum" nr 27 z 7 VII 1988).

Kraków

KS. JERZY CHMIEL

\author{
Ks. Kazimierz Hola
}

\title{
Z DZIALALNOSCI \\ POLSKIEGO TOWARZYSTWA TEOLOGICZNEGO W KRAKOWIE W ROKU 1987
}

I. Stan Towarzystwa

1.1. Walne Zebranie odbyło się dnia 23. I. 1987 o godz. $16.15 \mathrm{w}$ auli Wyższego Seminarium Duchownego w Krakowie przy ul. Podzamcze 8.

1.2. Walne Zebranie wybrało władze Towarzystwa w następującym składzie:

1.2.1. $\quad \mathrm{Z}$ a r z ą d prezes wiceprezes sekretarz biblifotekarz

- ks. doc. dr hab. Kazimierz Hola

- o. dr Jan Wichrowicz, OP

- ks. mgr Kazimierz Moskała

- ks. lic. Jan Bednarczyk

Walne Zebranie nie wybrało skarbnika Towarzystwa, lecz postanowiło, że zgodnie ze Statutem jego wyboru dokona najbliższe zebranie Zarządu (zob. punkt 1.3. - Zebranie Zarządu).

1.2.2. Komisja Kontrolująca

przewodniczący

członkowie

- ks. dr Kazimierz Waliczek

- ks. doc. dr hab. Jan Dyduch ks. dr Stefan Ryłko, CRL

1.2.3. Sąd Koleżeński przewodniczący członkowie 
- ks. mgr Józef Szczotkowski

- ks. dr Stefan Cichy

ks. dr Stanisław Bizuń

1.3. Zebranie Zarzacdu

W okresie sprawozdawczym Zarząd odbył 4 zebrania: 12. III. 1987; 4. VI. 1987; 6. X. 1987; 7. XII. 1987. Spośród ważniejszych. spraw poruszanych na zebraniach Zarządu i powziętych przezeń uchwał wypada tu wymienić następujące:

1) - w dniu 12. III. 1987:

Powołanie kierowników poszczególnych sekcji;

Wybór skarbnika - został nim ks. mgr Tomasz Boroń; Uchwalenie ramowego planu pracy Towarzystwa w nowej: kadencji Zarządu;

Organizacja sesji naukowej nt. „Eucharystia darem zobowiązującym";

2) - w dniu 4. VI. 1987:

Powołanie nowego kierownika Sekcji misjologicznej po śmierci ks. doc. dr hab. Antoniego Bacińskiego CM;

Rozpatrywanie zadań i trudności Sekcji wydawniczej.

3) - w dniu 6. X. 1987:

Powołanie Rady Konsultacyjnej przy Sekcji wydawniczej; Informacja Prezesa o zaproszeniu ks. prof. P. Schäfera $\mathrm{z}$ Uniwersytetu $\mathrm{w}$ Passau $\mathrm{z}$ referatem gościnnym na PTT.

4) - w dniu 7. XII. 1987:

Przygotowanie Walnego Zebrania:

Powołanie nowego kierownika Sekcji w Kalwarii Zebrzydowskiej.

1.4. Członkowie. Stan członków na dzień 31. XII. 1987 wynosił: członków zwyczajnych -270

" wspierających -34

razem -304

W roku sprawozdawczym przyjęto 5 nowych czlonków zwyczajnych:

ks. mgr Tomasz Boroń

ks. lic. Józef Morawa

o. dr hab. Tomasz Dąbek

ks. lic. Jan Palusiński

ks. dr Jerzy Woźniak CM

oraz 2 członków wspierających:

prof. dr Bolesław Makiej

mgr Wiktor Zębaty

1.5. Z $\mathrm{Zmarli}$ c złonkowie:

ks. doc. dr hab. Antoni Baciński CM

1.6. Odznaczenia: Honorowy medal Towarzystwa otrzymał ks. prof. dr hab. Stanisław Grzybek, pełniący od 35 lat funkcję 
kierownika Sekcji wydawniczej Towarzystwa. Medal wręczył odznaczonemu Prezes, dziękując mu za pełną poświęceń i trudów długoletnią pracę na wymienionym stanowisku dla dobra Towarzystwa.

\section{Działalność odczytowa Towarzystwa}

2.1. Sympozja i odczyty publiczne.

2.1.1. W dniu 9. IV. 1987 odbyło się w auli Wyższego Seminarium Duchownego Archidiecezji Krakowskiej Sympozjum Eucharystyczne przygotowane przez PTT przy współudziale PAT z następującym programem:

Otwarcie sesji

ks. doc. dr hab. Kazimierz Hoła: Wprowadzenie

o. opat prof. dr hab. Augustyn Jankowski OSB: „Eucharystia jako nowa pascha"

ks. prof. ndzw. dr hab. Adam Kubiś: „Eklezjalny charakter Ostatniej Wieczerzy"

bp dr Stanisław Nowak: „Duchowość ofiary wyrastająca z tajemnicy Eucharystii jako daru"

Dyskusja

ks. doc. dr hab. Stanisław Czerwik: „Niedzielne sprawowanie Eucharystii"

ks. dr Jan Szkodoń: „Eucharystia a małżeństwo i rodzina wymiar pastoralny"

Dyskusja

ks. dr Stefan Cichy: Podsumowanie.

2.1.2. Na zaproszenie Prezesa przybył do Krakowa ks. prof. P. Schäfer z Uniwersytetu w Passau i wygłosił w dniu 12. X. 1987 w gmachu Cantianum przy ul. Szujskiego 4 wobec przedstawicieli PTT i PAT interesujący wykład pt. „Ein bedeutsamer Schritt auf dem Weg zur Einheit" na temat rezultatów 4-letnich dociekań kręgu katolickich i protestanckich teologów, na życzenie Wspólnej Komisji Ekumenicznej, nad obowiązywalnością i sensem katolickich i protestanckich anatematyzmów z XVI w

2.1.3. W nawiązaniu do wykładu kss. prof. P. Schäfera Prezes Towarzystwa $\mathrm{w}$ piśmie $\mathrm{z}$ dnia 5. I. 1988 zwrócił się do Dziekana Wydziału Teologicznego PAT, ks. dr hab. Jerzego Chmiela, z propozycją zorganizowania wspólnie przez PTT i PAT sympozjum ekumenicznego, $\mathrm{z}$ udziałem przedstawicieli Luterańskiej Wspólnoty z Krakowa.

2.2. Sekcyjne zebrania naukowe

2.2.1. Sekcja filoz oficzna. Kierownik: ks. doc. dr hab. Henryk Piszkalski, CSsR. Odbyły się 2 zebrania z referatami: 
20. X. 1987 - dr Tadeusz Gawarecki ,Stan zdrowotny mieszkańców Krakowa w strefie zagrożenia ekologicznego";

17. XI. 1987 „Wpływ warunków biometeorologicznych na sprawność psychofizyczną człowieka".

2.2.2. Sekcja biblijno-liturgiczna. Kierownik: ks. dos. dr hab. Tomasz Jelonek. W roku sprawozdawczym nie wygłaszano referatów naukowych. Praca grupy przybrała inny charakter, jaki znalazł wyraz w trzech spotkaniach:

18. II. 1987 Spotkanie poświęcono omówienie profilu pracy Zespołu, ustalono rytm trzech spotkań rocznie, z których dwa będą miały charakter naukowy, a trzecie - naukowo-towarzyski. Omówiono również sprawy stworzenia serii wydawniczej „Biblia dla wszystkich”;

16. VI. 1987 Spotkanie w Seminarium Duchownym Ojców Bernardynów w Kalwarii Zebrzydowskiej z dwoma prelekcjami: 1) - o. lic. Augustyn Chadam „Kalwaria i jej misteria”; 2) - o. dr Edmund Świerczek „Próba wyjaśnienia dróżek Zaśnięcia Matki Bożej";

Ustalono również zasady wydawania serii „Biblia dla wszystkich" i wybrano zespół redakcyjny;

18. XI. 1987 Odbyła się dyskusja nad historią zbawienia jako przedmiotem wykładu na studiach teologicznych. Przyjęto wnioski, które pomogą w pracy dydaktycznej i zostaną przekazane Komisji Episkopatu do spraw ratio studiorum w seminariach polskich.

2.2.3. Sekcja a pologetyczno-religioznaweza. Kierownikiem Sekcji, po rezygnacji z tego stanowiska przez ks. prof. nadzw. dr hab. Adama Kubisia został przez Zarząd Towarzystwa w dniu 12. III. 1987 wybrany ks. dr Eukasz Kamykowski. Odbyły się trzy spotkania:

11. V. 1987 Ustalono, że Sekcja apologetyczno-religioznawcza ma mieć charakter naukowy, grupujący wykładowców teologii fundamentalnej i eklezjologii z teologicznych zakładów Południowej Polski;

5. X. 1987 z referatem ks. dr Jerzego Cudy nt. "Teologia jako teoria wiarygodnej społeczności";

7. XII. $1987 \mathrm{z}$ referatem ks. dr Jerzego Borowca pt. „Założenia eklezjologii Hansa Künga".

2.2.4. Sekcja dogmatyczno-moralna. Kierownik: o. dr Jan Wichrowicz, OP. Odbyło się 6 zebrań z referatami:

12. I. 1987 - o. dr Bogdan Brzuszek OFM: „Ks. Ludwik Wasilkowski i jego podręcznik dogmatyki"

16. II. 1987 - ks. dr Jacek Ryłko SDB: „Idealy i tendencje moralne współczesnej młodzieży polskiej w świetle Listu Apostolskiego Jana Pawła II do młodych całego świata" 
2. III. 1987 - o. dr Marian Lisowski OFMConv.: „Etos Ruchu i Stowarzyszenia Alkoholików Anonimowych. Ważniejsze elementy"

5. X. 1987 - o. dr Jan Wichrowicz OP: „Treści teologiczno-moralne w nowym mszale rzymskim"

9. XI. 1987 - ks. dr Jan Hojnowski SCJ: .,Uwagi na temat 1-go tomu serii książkowej ,Communio' poświęconego Eucharystii"

14. XII. 1987 - ks. prof. dr hab. Tadeusz Ślipko SJ: „Prawo a katolickie zasady moralne we współczesnych dyskusjach zachodnioniemieckich".

2.2.5. Sekcja prawa kanonicznego. Kierownik: ks. prof. nadzw. dr hab. Tadeusz Pieronek. Odbyło się jedno zebranie $\mathrm{z}$ jednym referatem:

16. XII. 1987 - ks. prof. nadzw. dr hab. Tadeusz Pieronek: „Stosunek sędziów kościelnych do ekspertyz lekarskich biegłych psychologów i psychiatrów"

2.2.6. Sekcja historyczna. Kierownik: o. dr hab. Marian Kanior OSB. Odbyły się 2 zebrania $z$ referatami:

21. I. 1987 - ks. Jan Pitoń: „Duszpasterstwo Polaków w Brazylii"

2. IV. 1987 - dr inż. arch. Jan Rączka: „Dziedzictwo kulturowe w zespołach sakralnych".

2.2.7. Sekcja mis jologiczna. W dniu 28. IV. 1987 zmarł jej kierownik, ks. doc. dr hab. Antoni Baciński CM. Na jego miejsce został przez Zarząd Towarzystwa w dniu 4. VI 1987 wybrany ks. mgr Jan Kaczmarek CM. Sekcja zorganizowała 2 zebrania:

w dniu 1. X. 1987 i 13. XI. 1987 na których nowy kierownik wraz ze swym zespołem dokonywał prac porządkujących dokumentację Sekcji. Nadto w dniu 16 X. 1987 odbyło się spotkanie członków Sekcji misjologicznej PTT z członkami Grupy misyjnej w parafii św. Szczepana w Krakowie, na którym ks. mgr Jan Kaczmarek wygłosił odczyt pt. „Jan Paweł II w Zairze”.

2.2.8. Sekcja socjologiczno-pastoralna. Kierownik: ks. dr Stefan Dobrzanowski. Odbyły się 3 posiedzenia $\mathrm{z}$ trzema referatami:

13. III. 1987 - ks. prof. dr hab. Jan Sieg SJ: „Prawda a ideologia w teologii wyzwolenia"

20. V. 1987 - o. dr Jan Chrapek CSMA: „Papież Jan Paweł II obrońcą zranionej godności człowieka"

15. XII. 1987 - ks. dr hab. Jan Wal: „Współczesne kierunki rozwoju teologii pastoralnej".

2.2.9. Sekcja w Katowi cach. Kierownik: ks. dr Stefan Cichy. Odbyły się 2 zebrania $z$ referatami: 
8. IV. 1987 - ks. dr hab. Stefan Koperek CR: „Polskie Kongresy Eucharystyczne"

19. X. 1987 - ks. dr Jerzy Pawlik: „Pielgrzymki piesze do Santiago de Compostela i obecne w Polsce jako element integrujący w Europie".

2.2.10. Sekcja w Tarnowie. Kierownik: ks. dr Bolesław Margański. Odbyły się 2 zebrania, na których wygłoszono referaty lub okolicznościowe przemówienia:

20. X. 1987 - ks. dr hab. W. Kania: „Recepcja św. Augustyna w Diecezji Tarnowskiej"

22. XI. 1987 Sekcja Koła, jako współorganizator i współuczestnik przygotowała uroczystość jubileuszową 50-lecia kapłaństwa ks. dr hab. W. Kani. Podczas uroczystej akademii laudację wygłosił ks. dr A. Nowak.

2.2.11. Sekcja w Tuchowie. Kierownik: ks. dr Stanisław Bafia CSsR. Odbyło się 6 zebrań, na których wygłoszono 14 odczytów:

24. II. 1987 - ks. prof. dr hab. Bolesław Kumor:

1) „Charyzmaty życia religijnego w Diecezji Tarnowskiej (1786-1986)"

2) ,.Upadek Kościoła greckokatolickiego - upadek Unii brzeskiej"

3) "Chrzest Litwy i początki organizacji kościelnej na Litwie" 21. III. 1987 - ks. doc. dr hab. W. Prężyna: „Powołanie kapłańskie na tle osobowości dojrzałej i religijnej"

25. IV. 1987 - prof. dr hab. Z. Płużek: „Jednostka i wspólnota” 23-24. X. 1987 - „Sw. Alfons: teolog - duszpasterz mistrz życia duchowego". Sympozjum z okazji dwusetnej rocznicy śmierci św. Alfonsa:

1) o. dr G. Velocci: „Sw. Alfons Liguori i jego dzieło w kontekście geograficzno-historycznym"

2) o. dr A. Bazielich: „Teologia modlitwy w nauce św. Alfonsa"

3) o. lic. B. Słota: „Pójście za Chrystusem według św. Alfonsa”

4) o. dr S. Stańczyk: „Mariologia św. Alfonsa”

5) o. dr G. Siwek: „Wpływ duchowości misjonarza na skuteczność przepowiadania misyjnego"

6) o. dr W. Bołoz: „Rola 'distacco' w duchowości św. Alfonsa”

7) o. dr G. Velocci: „Idee przewodnie teologii św. Alfonsa” 24. XI. 1987 - o. lic. E. Nocuń: „Kult MBN Pomocy w Polsce w II połowie XIX w."

15. XII. 1987 - o. dr J. Chaim: „Nadzieja chrześcijańska a świat ludzkich nadziei".

2.2.12. Sekcja w Kalwarii Zebrzydowskiej. Kierownikiem był do końca listopada 1987 o. lic. Andrzej Pabin OFM 
Po powołaniu go przez Kapitułę Prowincjalną na stanowisko prowincjała zrezygnował $z$ funkcji kierownika Sekcji PTT, a na jego miejsce został przez Zarzad w dniu 7. XII. 1987 wybrany o. lic. Franciszek Rydzak OFM.

Odbyły się 4 zebrania $\mathrm{z}$ referatami:

9. III. 1987 - o. dr Emilian Lenart: „Wybrane zagadnienia liturgiczno-duszpasterskie dotyczące ogólnego wprowadzenia do nowego mszału rzymskiego"

23. X. 1987 - o. dr Edmund Świerczek: „Rola Maryi w tajemnicy Chrystusa i Kościoła według Ewangelii św. Jana"

17. XI. 1987 - Zebranie nadzwyczajne $z$ okazji przyjazdu generalnego asystenta FZS (Trzeci Zakon Franciszkański) z Rzy$\mathrm{mu}$, o. Karola Schaffera, który w swoim referacie przedstawił sytuację FZS w dzisiejszym świecie i ustosunkował się do nowej reguly tercjarskiej opracowanej po Soborze Watykańskim II, a potwierdzonej przez papieża Pawła VI.

24. XI. 1987 - Prelekcje dokształcające na zebraniu młodych księży bernardyńskiej prowincji w zakresie duszpasterstwa grupowego: LSO, Oaz, Młodzieży Franciszkańskiej, Duszpasterstwa Powołań oraz duszpasterstwa FZS, z referatem traktującym o wprowadzeniu nowego mszału do liturgii o. dra E. Lenarta.

2.3. Podsumowanie statystyczne sesje i sympozja naukowe - 2 wykłady okolicznościowe $\quad-2$ zebrania sekcyjne $\quad-36$ ilość referatów i komunikatów -53

Kraków

KS. KAZIMIERZ HOEA

\section{Ks. Stefan Cichy}

\section{SPRAWOZDANIE Z SYMPOZJUM „NOVA ET VETERA" (IV) NA TEMAT: „MISTERIUM LITURGII - CZYM JEST?”}

W dniu 20 listopada 1986 r. Instytut Liturgiczny im. bł. Michała Giedroycia w Krakowie zorganizował sympozjum z okazji 100 rocznicy urodzin Odona Casela OSB (1886-1948) i 50 rocznicy śmierci ks. Michała Kordela (1892-1936). Sympozjum rozpoczęło się w auli Krakowskiego Metropolitarnego Seminarium Duchownego.

Otwarcia sympozjum dokonał dziekan Wydziału Teologicznego PAT w Krakowie ks. doc. dr hab. Jerzy Chmiel. Słowo wstępne wprowadzające w tematykę sympozjum i podające jego program wygłosił dyrektor Instytutu Liturgicznego ks. prof. dr hab. Wacław Swi erzawski. Do pełnienia funkcji przewodniczącego sesji przedpołudniowej poprosił on ks. doc. dr hab. Bogusława $\mathrm{Nadolskiego} \mathrm{TCh} \mathrm{z} \mathrm{Poznania,} \mathrm{zaś} \mathrm{do}$ pełnienia funkcji sekretarza ks. dra Stefana Cichego z Katowic.

Pierwszy wykład na temat Odo Casel i ruch liturgiczny wygłosił ks. prof. Achille Triacca SDB z Instytutu Liturgicznego Anselmianum 